\title{
Snail transmitters of schistosomiasis and other mollusks of medical and economic importance at the Simplício Queda Única Hydroelectric Plant, Southeast Brazil
}

\author{
Monica Ammon Fernandez ${ }^{[1]}$, Elizangela Feitosa da Silva ${ }^{[1]}$, \\ Rafael Alves Esteves ${ }^{[2]}$ and Silvana Carvalho Thiengo ${ }^{[1]}$
}

[1]. Laboratório de Malacologia, Instituto Oswaldo Cruz, Fundação Oswaldo Cruz, Rio de Janeiro, RJ, Brasil. [2]. Programa de Pós-Graduação em Meio Ambiente, Instituto de Biologia Roberto Alcântara Gomes, Universidade do Estado do Rio de Janeiro, Rio de Janeiro, RJ, Brasil.

\begin{abstract}
Introduction: This paper presents the results of an extensive survey of freshwater mollusks in the Simplicio Queda Unica Hydroelectric Development area, Southeast Brazil. Methods: Mollusks were collected between 2008 and 2013. All specimens were examined for the presence of larval trematodes. Results: In total, 12,507 specimens classified into 16 genera were obtained. Known snail vectors of schistosomiasis and fascioliasis and exotic species were identified, and new records are reported. Conclusions: No specimens parasitized by larval trematodes of medical interest were detected. However, the results reinforce the importance of surveillance in study areas vulnerable to the occurrence of schistosomiasis transmission.
\end{abstract}

Keywords: Mollusk vector. Trematode. Reservoir.

Although Brazil has hydrographical characteristics that favor hydraulic energy production, the construction of reservoirs has both irreversible environmental and social impacts. The transition from a lotic to a lentic environment favors the establishment mollusk populations that transmit parasites ${ }^{1}$, thereby facilitating the spread of schistosomiasis. Thus, epidemiological surveillance, registration of water bodies, identification and treatment of parasitized individuals, health education initiatives, and monitoring of the vector mollusks Biomphalaria glabrata (Say, 1818), Biomphalaria tenagophila (d'Orbigny, 1835), and Biomphalaria straminea (Dunker, 1848) are necessary ${ }^{2}$.

Our main objective was to characterize the distribution of snail vectors occurring in the Simplício Queda Única Hydroelectric Development (AHE Simplício) area and the associated larval forms of trematodes. Additionally, we aimed to provide support to implement measures to prevent the transmission of schistosomiasis and a baseline for future comparative analyses of changes in the composition of malacofauna resulting from hydroelectric power plant establishment.

The AHE Simplício is located on the Paraíba do Sul River in Southeast Brazil between municipalities Três Rios and Sapucaia

Corresponding author: MSc. Elizangela Feitosa da Silva

e-mail: efeitosa@ioc.fiocruz.br

Received 17 August 2017

Accepted 20 April 2018 in Rio de Janeiro and Chiador and Além Paraíba in Minas Gerais. Mollusks were colected in 2008 (July and October), 2009 (February, April, July, and October), 2010 (February, April, July, and October), and 2011 (March, April, and July), and 55 sampling stations were georeferenced (Figure 1). Of these, 27 were selected for monitoring (temporal analysis: 12 expeditions) because they are located at sites adversely affected by the construction. At these stations, the species were classified according to their frequency of occurrence ${ }^{3}$ into the categories of constant (present in more than $50 \%$ of samples), accessory ( $\leq 50 \%$ to $\geq 25 \%$ ), or accidental (occurring in $<25 \%$ of samples).

Malacological techniques and parasitological analysis were based on those used at the Laboratory of Malacology of the Oswaldo Cruz Institute/FIOCRUZ ${ }^{4-6}$. Samples were deposited at the Mollusk Collection of that institution. Some specimens could not be identified at the species level because only their shells were available or the specimens were immature.

Representatives of ten families were obtained (Figure 2). Although, owing to logistical difficulties, the sampling effort was not strictly standardized in all biotopes (direct collection with variations in search time), the absolute number of specimens collected in each expedition was recorded (631 specimens in July 2008; 757 in October 2008; 1,300 in February 2009; 882 in April 2009; 893 in July 2009; 740 in October 2009; 858 in February 2010; 2,572 in April 2010; 824 in July 2010; 644 in October 2010; 256 in March 2011; 844 in April 2011; and 1,316 in July 2011), totaling 12,507 mollusks. 


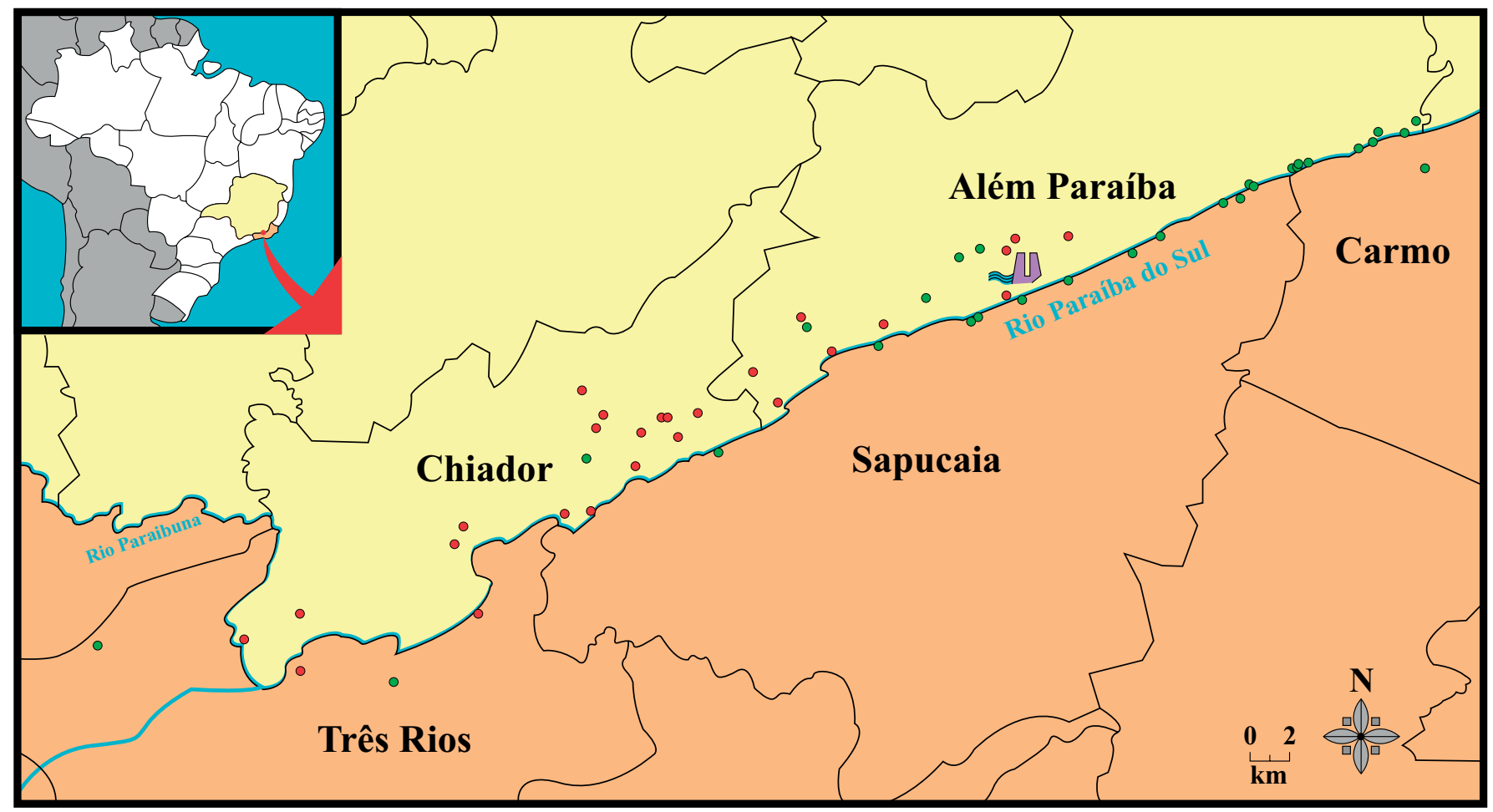

FIGURE 1: Sampling stations in the Simplício Queda Única Hydroelectric Development installation area, where surveys were conducted from July 2008 to July 2011. Red: sampling stations monitored in the temporal study.

The vector species for schistosomiasis and fasciolosis were represented by well-established populations: $B$. straminea and B. tenagophila were observed at 20 and 29 sampling stations, respectively, and, with the exception of Carmo, were found in all the municipalities surveyed. They were recorded sympatrically in 13 sampling stations: four in Três Rios (corresponding to $100 \%$ of the area surveyed in this municipality), three in Além Paraíba (13\%), and six in Chiador (35\%). Lymnaea columella Say, 1817 was found at 16 sampling stations $(29 \%$ of the analyzed biotopes) in Além Paraíba, Chiador, Sapucaia, and Três Rios. Regarding the other planorbids, the occurrence rates at the 55 sampling stations or only in the Paraíba do Sul River (19 stations) were, respectively, as follows: $36.4 \%$ and $5.3 \%$ for Drepanotrema anatinum (d'Orbigny, 1835); 21.8\% and 5.3\% for Drepanotrema cimex (Moricand, 1837); $14.5 \%$ and $5.3 \%$ for Drepanotrema depressissimum (Moricand, 1839); 21.8\% and $5.3 \%$ for Drepanotrema lucidum (Pfeiffer, 1839), and 27.3\% and $10.5 \%$ for Gundlachia sp. No species of Ancylinae were found in the Paraíba do Sul River, whereas in the municipalities, the percentage occurrences were $1.8 \%$ for Burnupia sp. and Hebetancylus sp., 3.6\% for Gundlachia radiata (Guilding, 1828), 5.4\% for Gundlachia ticaga (Marcus \& Marcus, 1962), and $7.3 \%$ for Ferrissia sp.

The exotic species Physa acuta Draparnaud, 1805 was found at only nine sampling stations $(16.4 \%$ of the sampling area), whereas the native species Physa marmorata Guilding, 1828 was present in 27 (49.1\%) biotopes. However, considering only the Paraíba do Sul River, Physa acuta and P. marmorata were found at $26.3 \%$ and $5.3 \%$ of the sampling stations, with one biotope being inhabited by both species. Melanoides tuberculata (Müller, 1774), was found at 12 sampling stations, corresponding to $21.8 \%$ of the area surveyed. Some specimens of Omalonyx sp. were collected from the marginal vegetation of the sampling stations in the municipalities of Além Paraíba, Chiador, and Sapucaia. Bivalvia specimens were found at 33 stations, with Sphaeriidae members predominating (26 sampling stations). We highlight the occurrence of two invasive exotic species in seven sampling stations in the Paraíba do Sul River, namely, Corbicula fluminea (Müller, 1774) and Corbicula largillierti (Philippi, 1844). These Corbiculidae were also observed in four other sampling stations in Chiador and Sapucaia (Figure 2), with the two species occurring together in Jamapará.

Based on a survey of larval helminths harbored by the mollusks, although we detected cercariae, neither Schistosoma mansoni Sambon, 1907 nor Fasciola hepatica Linnaeus, 1758 were found. Of the six parasitized species, B. tenagophila was identified as having the highest number of parasitic interactions: armatae cercaria (Xiphidiocercaria), brevifurcate apharyngeate cercaria (Furcocercous), echinostome cercaria (Echinostome), ornatae cercaria (Xiphidiocercaria), strigea cercaria (Furcocercous), ubiquita cercaria (Xiphidiocercaria), and virgulate cercaria (Xiphidiocercaria). The other mollusks were parasitized by a single larval type: armatae cercaria in $D$. lucidum, echinostome cercaria in P. marmorata, ornatae cercaria in L. columella, ubiquita cercaria in Pomacea sp., and strigea cercaria in B. straminea. Only in July 2010 were no parasitized mollusks found. The most common cercariae types were ubiquita cercaria and ornatae cercaria, observed in eight of 


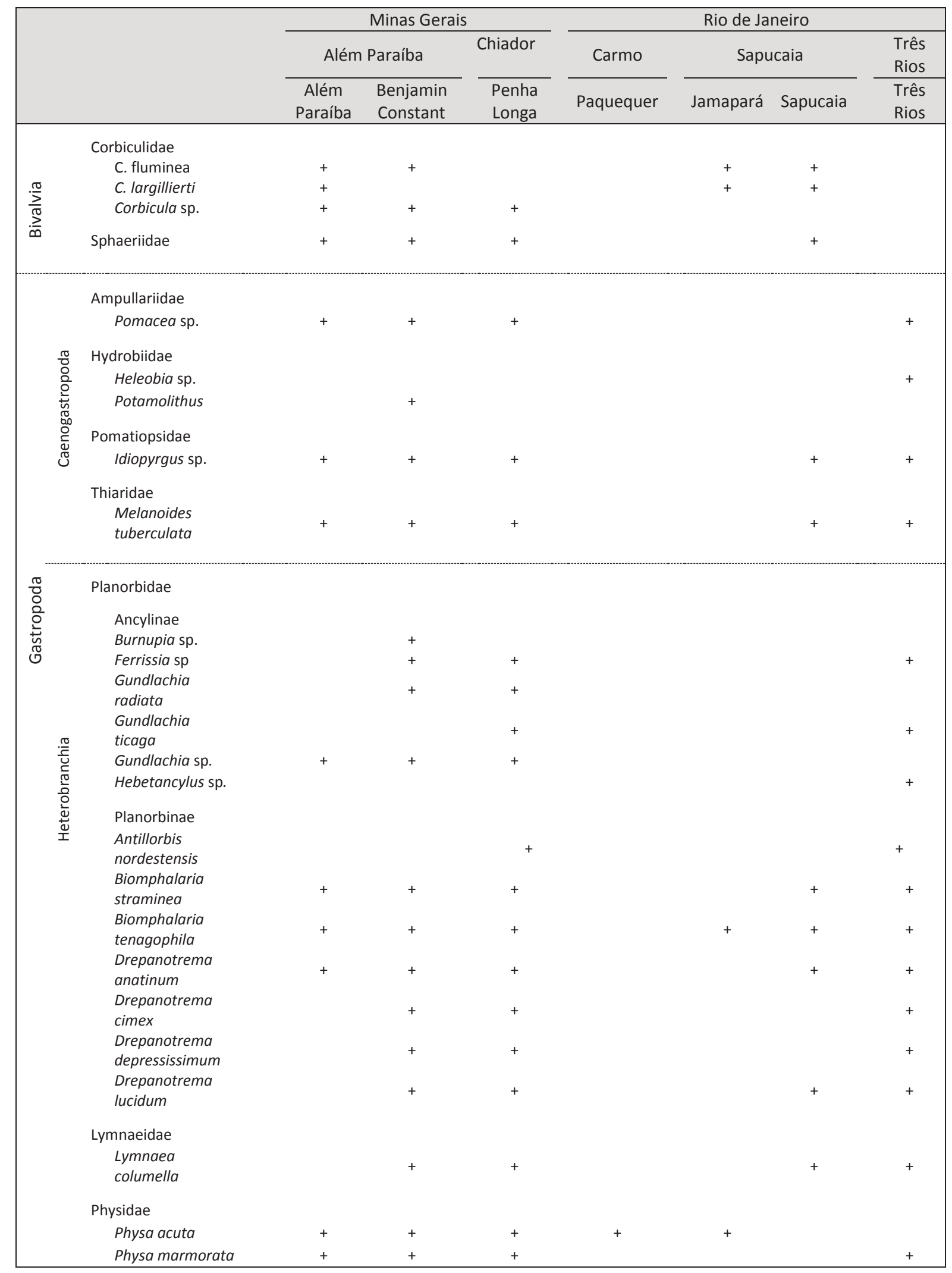

FIGURE 2: Freshwater malacofauna from the area influenced by the Simplício Queda Única Hydroelectric Development, Minas Gerais/Rio de Janeiro, collected from 55 sampling stations between July 2008 and July 2011. 


\begin{tabular}{|c|c|c|c|c|c|c|c|c|c|c|c|c|}
\hline \multirow{2}{*}{$\begin{array}{l}\text { Sampling } \\
\text { stations }\end{array}$} & \multicolumn{2}{|c|}{2008} & \multicolumn{4}{|c|}{2009} & \multicolumn{4}{|c|}{2010} & \multicolumn{2}{|c|}{2011} \\
\hline & July & October & February & April & July & October & February & April & July & October & March & April \\
\hline 1 & $\begin{array}{l}\text { Bt, Gu, } \\
\text { Lc, Mt }\end{array}$ & $\mathrm{LC}, \mathrm{Pa}$ & & Mt & $\begin{array}{l}\mathrm{Bt}, \mathrm{Mt} \text {, } \\
\mathrm{Pa}, \mathrm{Po}\end{array}$ & Lc & $\mathrm{Mt}, \mathrm{Po}$ & Mt, Po & & $\mathrm{Mt}, \mathrm{Pa}$ & $\mathrm{Mt}$ & \\
\hline 2 & $\begin{array}{l}\text { Da, Dd, } \\
\text { Pm }\end{array}$ & $\mathrm{Bt}, \mathrm{Da}$ & $\mathrm{Da}, \mathrm{Pm}$ & $\begin{array}{l}\mathrm{Da}, \\
\mathrm{Pm}\end{array}$ & $\mathrm{Da}, \mathrm{Pm}$ & $\begin{array}{l}\text { Bt, Da, Dd, } \\
\text { Pm }\end{array}$ & $\mathrm{Bt}, \mathrm{Id}, \mathrm{Pm}$ & $\mathrm{Da}, \mathrm{Dc}, \mathrm{DI}$ & & $\mathrm{Da}$ & $\mathrm{Bt}, \mathrm{Da}$ & $\mathrm{Bt}, \mathrm{Da}, \mathrm{Lc}$ \\
\hline 3 & Bs & Bs & Po & Bs, Po & $\begin{array}{c}\text { Bs, Bt, } \\
\text { Po }\end{array}$ & Pm, Po & $\begin{array}{l}\text { Bs, Mt, } \\
\text { Po }\end{array}$ & $\begin{array}{l}\text { Bs, Gr, } \\
\text { Mt, Pm, } \\
\text { Po }\end{array}$ & $\begin{array}{l}\text { Bs, Mt, } \\
\text { Po }\end{array}$ & $\begin{array}{l}\mathrm{Bt}, \mathrm{Mt}, \\
\text { Po }\end{array}$ & $\begin{array}{l}\text { Bs, Mt, } \\
\text { Po }\end{array}$ & Bs, Po \\
\hline 4 & $\mathrm{Bt}, \mathrm{Dc}$ & $\begin{array}{l}\text { Bt, Dc, } \\
\text { Pm }\end{array}$ & $\mathrm{Bt}, \mathrm{Gu}$ & $\mathrm{Bt}, \mathrm{Gu}$ & & & $\mathrm{Bt}, \mathrm{Pa}$ & & Bs, Gu & $\mathrm{Bt}$ & & $\mathrm{Bt}$ \\
\hline 5 & $\mathrm{Bs}$ & $\mathrm{Bs}, \mathrm{Pm}$ & $\mathrm{Bs}$ & $\begin{array}{l}\mathrm{Da}, \\
\mathrm{Pm}\end{array}$ & $\mathrm{Bt}$ & & $\mathrm{Bs}$ & & & & & $\mathrm{Bt}$ \\
\hline 6 & $\begin{array}{l}\text { Bs, Mt, } \\
\text { Pm }\end{array}$ & $\mathrm{Pm}$ & & $\mathrm{Mt}$ & $\mathrm{Pm}$ & Pm & Mt & Mt & $\mathrm{Mt}, \mathrm{Pm}$ & $\mathrm{Mt}, \mathrm{Pm}$ & $\mathrm{Mt}, \mathrm{Pm}$ & $\mathrm{Mt}, \mathrm{Pm}$ \\
\hline 7 & $\begin{array}{l}\text { Bs, Pm, } \\
\text { Po }\end{array}$ & Po & Bt, Lc, Po & $\begin{array}{l}\text { Bs, Lc, } \\
\text { Po }\end{array}$ & $\mathrm{Bs}, \mathrm{LC}$ & $\mathrm{Bs}, \mathrm{Da}, \mathrm{Gu}$ & Bs, Po & $\begin{array}{c}\text { Bs, Da, } \\
\text { Gu, Lc, } \\
\text { Po }\end{array}$ & $\begin{array}{l}\text { Bs, Lc, } \\
\text { Pm, Po }\end{array}$ & Bs, Lc, Po & & Bs, Po \\
\hline 8 & & & Bs, Po & $\begin{array}{l}\text { Bs, } \\
\text { Da, } \\
\text { Po }\end{array}$ & Bs, Po & $\begin{array}{c}\text { Bs, Gu, Pm, } \\
\text { Po }\end{array}$ & Bs, Po & Bs, Po & $\begin{array}{l}\text { Bs, Gu, } \\
\text { Po }\end{array}$ & $\begin{array}{l}\text { Bs, Pm, } \\
\text { Po }\end{array}$ & & \\
\hline 9 & Bs, Po & $\mathrm{Pm}$ & $\mathrm{Pm}$ & $\begin{array}{l}\mathrm{Da}, \\
\mathrm{Pm}\end{array}$ & $\mathrm{Pm}$ & $\mathrm{Gu}, \mathrm{Pm}$ & $\mathrm{Pm}$ & & & & Bs, Po & $\mathrm{Da}, \mathrm{Pm}$ \\
\hline 10 & & $\begin{array}{l}\text { Bt, Da, } \\
\mathrm{Dc}, \mathrm{Pm}\end{array}$ & $\begin{array}{c}\text { Bt, Da, } \\
\text { Dd, DI, } \\
\text { Gu }\end{array}$ & $\begin{array}{l}\text { Bt, Da, } \\
\text { Dl }\end{array}$ & $\mathrm{DI}, \mathrm{Pm}$ & & & & & $\mathrm{Pa}$ & & \\
\hline 11 & & $\mathrm{Bt}, \mathrm{DI}$ & $\mathrm{DI}$ & $\begin{array}{l}\text { Bt, Da, } \\
\text { Dc, } \\
\text { Pm }\end{array}$ & $\mathrm{Bt}$ & $\mathrm{DI}$ & $\mathrm{Bt}, \mathrm{DI}$ & & & $\mathrm{DI}, \mathrm{Id}$ & $\mathrm{Bt}, \mathrm{DI}$ & Bs \\
\hline 12 & & $\begin{array}{c}\text { Bt, Da, } \\
\text { Dc, Dl, Lc }\end{array}$ & $\mathrm{Bt}, \mathrm{DI}$ & $\begin{array}{c}\text { Bt, Da, } \\
\text { DI }\end{array}$ & $\begin{array}{l}\mathrm{Bt}, \mathrm{Da}, \\
\mathrm{DI}, \mathrm{Gu}\end{array}$ & Bt, Da, DI & $\mathrm{DI}$ & $\mathrm{DI}$ & & $\mathrm{Da}$ & & $\begin{array}{c}\mathrm{Bt}, \mathrm{Gr}, \\
\mathrm{Pm}\end{array}$ \\
\hline 13 & Bs & & Bs & & & $\mathrm{Bs}, \mathrm{Dd}, \mathrm{DI}$ & & Bs & & Gu & & \\
\hline 14 & $\mathrm{Bt}, \mathrm{DI}$ & $\begin{array}{l}\text { Bt, Lc, } \\
\text { Pm }\end{array}$ & $\begin{array}{c}\text { Bs, Dl, Pa, } \\
\text { Po }\end{array}$ & $\begin{array}{l}\text { Bs, } \\
\text { Pm, } \\
\text { Po }\end{array}$ & $\mathrm{Pa}$ & Bs & $\mathrm{Bs}, \mathrm{DI}, \mathrm{Pa}$ & $\mathrm{Bs}, \mathrm{Pa}$ & $\mathrm{Bs}$ & $\mathrm{Bt}, \mathrm{Pm}$ & $\begin{array}{c}\mathrm{Bs}, \mathrm{Bt}, \\
\mathrm{Gu}, \mathrm{Pa}, \\
\mathrm{Po}\end{array}$ & $\begin{array}{l}\mathrm{Bs}, \mathrm{Bt}, \\
\mathrm{Gu}, \mathrm{Pa}\end{array}$ \\
\hline 15 & & & $\mathrm{Bt}, \mathrm{Dc}$ & Mt & $\mathrm{Dd}$ & $\mathrm{Bt}, \mathrm{Pm}$ & $\mathrm{Bt}, \mathrm{Pm}$ & Bt & $\begin{array}{c}\text { Da, Dc, } \\
\text { Gu }\end{array}$ & Bt & & $\begin{array}{c}\text { Bt, Dc, } \\
\text { Gu }\end{array}$ \\
\hline 16 & $\begin{array}{c}\mathrm{Bt}, \mathrm{Da}, \\
\mathrm{Lc}, \mathrm{Mt}, \\
\mathrm{Pm}\end{array}$ & Mt & $\mathrm{Bt}, \mathrm{Dd}, \mathrm{Mt}$ & Mt & Mt & Mt & & & & $\begin{array}{l}\mathrm{Bt}, \mathrm{Da}, \\
\mathrm{Dc}, \mathrm{Pm}\end{array}$ & & \\
\hline 17 & & $\begin{array}{l}\mathrm{Fe}, \mathrm{Lc}, \\
\mathrm{Pm}\end{array}$ & $\mathrm{Bt}, \mathrm{Da}, \mathrm{Pm}$ & $\mathrm{Fe}$ & & & & & $\mathrm{Gu}$ & & & \\
\hline 18 & Bt & $\mathrm{Bt}, \mathrm{Pm}$ & & Gu & Gu & $\mathrm{Pm}$ & $\mathrm{Bt}, \mathrm{LC}$ & $\mathrm{Dd}$ & & & An & \\
\hline 19 & $\begin{array}{l}\text { Bt, Lc, } \\
\text { Pm }\end{array}$ & $\begin{array}{l}\text { Bt, Lc, } \\
\text { Pm }\end{array}$ & $\begin{array}{c}\text { An, Bt, Lc, } \\
\text { Pm }\end{array}$ & $\begin{array}{c}\text { Bs, Bt, } \\
\text { Da, Lc, } \\
\text { Pm }\end{array}$ & $\mathrm{Bt}$ & $\begin{array}{c}\text { An, Bt, Lc, } \\
\text { Pm }\end{array}$ & $\mathrm{Bt}$ & $\begin{array}{l}\mathrm{Bt}, \mathrm{Da}, \\
\mathrm{Pm}\end{array}$ & $\mathrm{Bt}$ & $\mathrm{Bt}, \mathrm{Da}, \mathrm{Lc}$ & $\begin{array}{l}\text { Bt, Lc, } \\
\text { Pm }\end{array}$ & $\begin{array}{l}\text { Bt, Lc, } \\
\text { Pm }\end{array}$ \\
\hline 20 & $\begin{array}{l}\text { Bt, Da, } \\
\text { Dc, Gt, } \\
\text { Pm }\end{array}$ & $\begin{array}{l}\mathrm{Bt}, \mathrm{Da} \\
\mathrm{Dc}, \mathrm{Pm}\end{array}$ & $\begin{array}{c}\text { Bs, Bt, Dd, } \\
\text { Pm }\end{array}$ & $\begin{array}{c}\mathrm{Bt}, \mathrm{Da}, \\
\mathrm{Gu}, \\
\mathrm{Pm}\end{array}$ & $\mathrm{Da}, \mathrm{Gu}$ & $\mathrm{Bt}$ & $\begin{array}{l}\text { Bt, Dd, } \\
\text { Pm }\end{array}$ & $\begin{array}{l}\text { Da, Dd, } \\
\text { Pm }\end{array}$ & $\begin{array}{c}\mathrm{Bt}, \mathrm{Dc}, \\
\mathrm{Gu}\end{array}$ & $\begin{array}{l}\mathrm{Da}, \mathrm{Dc} \\
\mathrm{Pm}\end{array}$ & & $\mathrm{Bt}, \mathrm{Pm}$ \\
\hline 21 & & $\begin{array}{l}\text { Bt, Da, } \\
\text { Pm }\end{array}$ & & $\mathrm{Bt}, \mathrm{DI}$ & $\begin{array}{c}\mathrm{Bt}, \mathrm{Da}, \\
\mathrm{Pm}\end{array}$ & $\mathrm{Bt}, \mathrm{Dc}, \mathrm{Pm}$ & $\begin{array}{l}\mathrm{Bt}, \mathrm{Da}, \\
\mathrm{Dc}, \mathrm{Pm}\end{array}$ & & $\mathrm{Bt}$ & $\mathrm{Da} \mathrm{Dc}$ & $\mathrm{Gu}$ & $\begin{array}{l}\mathrm{Da}, \mathrm{Gu}, \\
\mathrm{Pm}\end{array}$ \\
\hline 22 & $\mathrm{Bt}, \mathrm{Gu}$ & $\mathrm{Gt}$ & $\mathrm{Bt}, \mathrm{Da}, \mathrm{Lc}$ & $\begin{array}{l}\mathrm{Bs}, \\
\mathrm{Pm}\end{array}$ & $\begin{array}{c}\text { Bs, Bt, } \\
\text { Pm }\end{array}$ & $\mathrm{Bt}$ & & & $\begin{array}{l}\mathrm{Bs}, \mathrm{Fe}, \\
\mathrm{Lc}, \mathrm{Pm}\end{array}$ & $\mathrm{Bs}, \mathrm{Pm}$ & & $\begin{array}{c}\mathrm{Bs}, \mathrm{Bt}, \\
\mathrm{Pm}\end{array}$ \\
\hline 23 & Bs & $\begin{array}{l}\mathrm{Bs}, \mathrm{Da}, \\
\mathrm{Dc}, \mathrm{Lc}, \\
\mathrm{Pm}\end{array}$ & $\begin{array}{c}\text { Bs, Bt, Dc, } \\
\text { DI, Pm }\end{array}$ & Bs & & & & Gu & & Bs, Lc & $\mathrm{DI}, \mathrm{Gu}$ & $\mathrm{Bs}, \mathrm{Gu}$ \\
\hline 24 & $\begin{array}{c}\text { Bt, Da, } \\
\text { Pm }\end{array}$ & $\mathrm{Bt}$ & $\mathrm{Bt}, \mathrm{Pm}$ & $\mathrm{Bt}, \mathrm{Da}$ & $\begin{array}{l}\mathrm{Bt}, \mathrm{Da}, \\
\mathrm{Gu}, \mathrm{Pm}\end{array}$ & $\mathrm{Bt}$ & $\begin{array}{l}\mathrm{Bt}, \mathrm{Gu}, \\
\mathrm{Pm}\end{array}$ & $\mathrm{Bt}$ & & $\begin{array}{l}\mathrm{Bt}, \mathrm{Da}, \\
\mathrm{Dc}, \mathrm{Pm}\end{array}$ & & $\mathrm{Bt}, \mathrm{Pa}$ \\
\hline 25 & $\mathrm{Bt}, \mathrm{DI}$ & $\mathrm{DI}$ & $\mathrm{Bt}, \mathrm{DI}$ & & & $\mathrm{Bt}, \mathrm{DI}$ & & $\mathrm{Bt}, \mathrm{Da}$ & $\mathrm{DI}$ & $\mathrm{Bt}, \mathrm{DI}$ & $\mathrm{Bt}, \mathrm{DI}, \mathrm{LC}$ & $\mathrm{Bt}, \mathrm{Da}, \mathrm{DI}$ \\
\hline 26 & & $\mathrm{Bt}, \mathrm{Fe}, \mathrm{Mt}$ & $\begin{array}{c}\text { An, Bs, Dl, } \\
\text { Mt, Pm }\end{array}$ & $\begin{array}{l}\mathrm{Mt}, \\
\mathrm{Pm}\end{array}$ & $\mathrm{Mt}, \mathrm{Pm}$ & Bt & & $\mathrm{Mt}, \mathrm{Pm}$ & Mt & Mt & & \\
\hline 27 & & $\begin{array}{l}\text { Bt, Da, } \\
\text { Pm }\end{array}$ & $\begin{array}{l}\text { Bs, Bt, Id, } \\
\text { Lc, Pm, } \\
\text { Po }\end{array}$ & $\begin{array}{l}\text { Bs, Bt, } \\
\text { Pm, } \\
\text { Po }\end{array}$ & $\begin{array}{l}\text { Bs, Bt, } \\
\text { Dl, Gt, } \\
\text { Id, Po }\end{array}$ & $\begin{array}{c}\text { Bs, Da, Dd, } \\
\text { Dl, Id, Lc, } \\
\text { Pm, Po }\end{array}$ & $\begin{array}{l}\text { Bs, Dl, Id, } \\
\text { Mt, Pm, } \\
\text { Po }\end{array}$ & $\begin{array}{c}\text { Da, DI, Id, } \\
\text { Mt }\end{array}$ & $\begin{array}{l}\text { Bs, Da, } \\
\text { Dc, DI, } \\
\text { Lc, Pm, } \\
\text { Po }\end{array}$ & $\begin{array}{l}\mathrm{Bt}, \mathrm{Hb} \\
\mathrm{Lc}, \mathrm{Pm}\end{array}$ & $\begin{array}{c}\text { Dc, DI, } \\
\text { HI, Pm, } \\
\text { Po }\end{array}$ & DI, Po \\
\hline
\end{tabular}

FIGURE 3: Temporal analysis of freshwater malacofauna in the area influenced by the Simplício Queda Única Hydroelectric Development, Minas Gerais/Rio de Janeiro, at 27 sampling stations between July 2008 and April 2011. Bt: Biomphalaria tenagophila; Gu: Gundlachia sp.; Lc: Lymnaea columella; Pa: Physa acuta; Mt: Melanoides tuberculata; Po: Pomacea sp; Da: Drepanotrema anatinum; Dd: Drepanotrema depressissimum; Pm: Physa marmorata; Id: Idiopyrgus sp.; Dc: Drepanotrema cimex; DI: Drepanotrema lucidum; Bs: Biomphalaria straminea; Gr: Gundlachia radiata; Fe: Ferrissia sp.; An: Antillorbis nordestensis; Gt: Gundlachia ticaga; HI: Heleobia sp.; Hb: Hebetancylus sp. 
the 13 expeditions conducted, throughout the year. Brevifurcate apharyngeate cercaria and virgulate cercaria were observed only in July and October 2008, respectively.

The temporal study revealed a prevalence of $P$. marmorata ( $88.9 \%$ occurrence rate), followed by B. tenagophila $(81.5 \%)$. $B$. stramine $a$ and $B$. tenagophila were detected sympatrically at 11 of the 27 stations monitored and only at a sampling station were these species not found. Individually, B. tenagophila and $B$. straminea had populations at 10 and five sampling stations, respectively. In Chiador, both species were observed during different expeditions until October 2010, and thereafter, were found to occur sympatrically (Figure 3).

Lymnaea columella was obtained during all 12 expeditions, with the highest occurrence in October 2008 (six sampling stations).

The lowest species richness was recorded in April 2009 and July 2010, when only 11 species were collected in each expedition. Based on the frequency of occurrence, no species was classified as constant. B. tenagophila and P. marmorata were the only accessory species (frequency of occurrence of $33.0 \%$ and $27.8 \%$, respectively), whereas all the other species were classified as accidental: Antillorbis nordestensis (Lucena, $1954), 1.2 \%$; B. straminea, $20.7 \%$; D. anatinum, $16.9 \%$; $D$. cimex, $6.8 \%$; D. depressissimum, 3.4\%; D. lucidum, 12.3\%; Ferrissia sp., 1.2\%; G. radiata, 0.9\%; G. ticaga, 1.2\%; Gundlachia sp., 8.6\%; Hebetancylus sp., 0.3\%; Heleobia sp., $0.3 \%$; Idiopyrgus sp., 2.2\%; L. columella, 9.9\%; M. tuberculata, 11.1\%; P. acuta, 3.7\%; and Pomacea sp., 12.0\%.

However, at the generic level, Biomphalaria was constant (frequency of occurrence of 53.7\%), Drepanotrema and Physa were accessory (39.5\% and $31.5 \%$, respectively), and the remaining genera were accidental. Considering each year, Biomphalaria was constant $(61.1 \%$ in 2008 and $63.9 \%$ in 2009 ) and accessory (43.5\% in 2010 and $46.3 \%$ in 2011). B. tenagophila was accessory $(42.6 \%$ in $2008,39.8 \%$ in 2009 , and $29.6 \%$ in 2011) and accidental (23.1\% in 2010), and $B$. straminea was accidental (18.5\% in $2008,24.1 \%$ in 2009 , $20.4 \%$ in 2010 , and $16.7 \%$ in 2011). Similarly, L. columella and $M$. tuberculata were accidental: $16.7 \%$ and $9.2 \%$ (2008), $9.2 \%$ and $10.1 \%$ (2009), $8.3 \%$ and $14.8 \%$ (2010), and $7.4 \%$ and $7.4 \%$ (2011), respectively.

The frequency of occurrence of the exotic species $P$. acuta and the native species $P$. marmorata for each year of the survey were, respectively, as follows: $1.8 \%$ and $37 \%$ in $2008,2.8 \%$ and $34.3 \%$ in $2009,4.6 \%$ and $21.3 \%$ in 2010 , and $5.5 \%$ and $18.5 \%$ in 2011 .

The malacofauna found in the AHE Simplício area are consistent with the observation of Thiengo et al. ${ }^{7}$ for the State of Rio de Janeiro. Regarding Minas Gerais, the findings of this study extend the geographical distributions of $B$. straminea and B. tenagophila to Além Paraíba and Chiador, thereby increasing the records of occurrence ${ }^{8}$ to 143 and 63 municipalities, respectively.

In the area influenced by the Rosal Hydroelectric Plant ${ }^{9}$ reduced abundance of $B$. tenagophila and B. glabrata was observed after reservoir construction. Following onset of the first cases of schistosomiasis in the vicinity of the Americana Dam ${ }^{10}$ in São Paulo, a study on malacofauna was conducted, and six $S$. mansoni transmission foci were identified by examining 1,101 specimens of $B$. tenagophila. These findings, coupled with the coexistence of $B$. straminea and B. tenagophila in the area influenced by the AHE Simplício plant, reinforce the need for a continuation of these studies, including a quantitative evaluation.

The record of L. columella in the studied area extends this species' distribution to Minas Gerais ${ }^{11}$, increasing the number of inhabited municipalities to 42 .

Our identification of the invasive exotic mollusks $C$. fluminea, C. largillierti, M. tuberculata, and P. acuta is noteworthy. The first two species are currently widely distributed in several river basins and are having irreversible socioeconomic or environmental effects, such as causing a reduction in native bivalve populations ${ }^{12}$. In the reservoir of the Manso Power Plant in the State of Mato Grosso ${ }^{13}$ M. tuberculata was introduced after February 2009 and showed the highest relative abundance (94.96\%) among the nine species recorded between April 2009 and October 2010. The present study is the first to report the occurrence of M. tuberculata in Além Paraíba, Chiador, and Três Rios.

We highlight the predominance of the native species $P$. marmorata over the exotic species $P$. acuta in the study area because, in the Serra da Mesa Hydroelectric Power Plant reservoir, a population decline occurred in $P$. marmorata after the introduction of P. acuta ${ }^{14}$. Although it was considered an accidental species $(<25 \%$ of samples) in the present study, the frequency of occurrence of $P$. acuta increased during the temporal study, confirming its dispersal and colonization capacity in the reservoir environments of hydroelectric plants.

Regarding species of Ancylinae, although G. radiata occurs in seven Brazilian states (Alagoas, Amazonas, Goiás, Pará, Paraíba, Pernambuco, and Rio de Janeiro) ${ }^{15}$, occurrence in Minas Gerais was recorded for the first time.

Of the larval forms of trematodes detected, brevifurcate apharyngeate cercaria and echinostome cercaria stand out among the cercariae types found due to their importance as possible causal agents of human cercarial dermatitis and for being associated with the transmission of Echinostoma spp., respectively.

The presence of two known snail vectors of schistosomiasis, the environmental transformations resulting from the installation of reservoirs, and the establishment of resorts that encourage the contact between people and water, define the area of the AHE Simplício Queda Única as vulnerable to the transmission of schistosomiasis. Moreover, we highly ghted the proximity of the municipality of Sumidouro (approximately $40 \mathrm{~km}$ ), in Rio de Janeiro, where there is transmission of schistosomiasis.

Although the burgeoning demand for energy generation in the country is unequivocal, the Brazilian energy matrix undoubtedly contributes to the fragmentation of biomes 
and modification of river regimes. Therefore, adoption of multidisciplinary approaches in the areas of health, environment, and education is imperative to reconcile regional development with a good quality of human life and a healthy environment through public health policies and appropriate environmental management.

\section{Acknowledgments}

We acknowledge the team of the Laboratory of Malacology of the Oswaldo Cruz Institute/Fundação Oswaldo Cruz for their help in collecting and processing the specimen samples, Dr. Sonia Barbosa dos Santos and Dr. Luiz Eduardo Macedo de Lacerda for identifying the ancilids, and Furnas Centrais Elétricas for logistical support during field work.

\section{Conflict of interest}

The authors declare that there is no conflict of interest.

\section{Financial support}

Funded by Instituto Oswaldo Cruz/Fundação Oswaldo Cruz and Furnas Centrais Elétricas Project number IOC-003-LIV-08-2-2.

\section{REFERENCES}

1. Thiengo SC, Fernandez MA. Moluscos límnicos em reservatórios de Usinas Hidrelétricas no Brasil: aspectos biológicos e epidemiológicos. In: Carvalho OS, Coelho PMZ, Lenzi HL, organizadores. Schistosoma mansoni \& Esquistossomose: uma visão multidisciplinar. Rio de Janeiro: Editora FIOCRUZ; 2008. p. 435-57.

2. Ministério da Saúde (MS). Secretaria de Vigilância em Saúde. Vigilância da Esquistossomose Mansoni: Diretrizes Técnicas. $4^{\mathrm{a}}$ edição. Brasília: MS; 2014. 144p.

3. Dajoz R. Ecologia Geral. 4ª edição. Petrópolis: Editora Vozes; 1983. 472p.

4. Fernandez MA, Thiengo SC, Amaral RS. Técnicas alacológicas. In: Amaral RS, Thiengo SC, Pieri OS, editores. Vigilância e controle de moluscos de importância médica: Diretrizes técnicas. Brasília: Editora do Ministério da Saúde; 2008. p. 43-70.

5. Schell SC. How to know the trematodes. $3^{\text {rd }}$ edition Dubuque, Iowa: Brown Co. Publishiers; 1970. 330p.
6. Fukuda H, Haga T, Tatara Y. Niku-nuki: a useful method for anatomical and DNA studies on shell-bearing molluscs. Zoosymposia. 2008;1:15-38.

7. Thiengo SC, Fernandez MA, Boaventura MFF, Santos SB, Mattos AC. Freshwater snails and schistosomiasis mansoni in the state of Rio de Janeiro, Brazil: II - Centro Fluminense Mesoregion. Mem Inst Oswaldo Cruz 2002;97:621-26.

8. Carvalho OS, Amaral RS, Dutra LV, Scholte RGC, Guerra MAM. Distribuição espacial de Biomphalaria glabrata, B. straminea e $B$. tenagophila, hospedeiros intermediários de Schistosoma mansoni no Brasil. In: Carvalho OS, Coelho PMZ, Lenzi HL (orgs). Schistosoma mansoni \& Esquistossomose, uma visão multidisciplinar. Rio de Janeiro, Editora FIOCRUZ; 2008. p. 393-418.

9. Rezende HR, Sessa PA, Ferreira AL, Santos CB, Leite GR, Falqueto A. Efeitos da implantação da Usina Hidrelétrica de Rosal, Rio Itabapoana, estados do Espírito Santo e Rio de Janeiro, sobre anofelinos, planorbídeos e flebotomíneos. Rev Soc Bras Med Trop. 2009;42(2):160-4.

10. Magalhães LA, Dias LCS, Piza JT, Takaku L, Pereira AA. Aspectos epidemiológicos da esquistossomose mansônica na região da Represa de Americana, Estado de São Paulo, Brasil. Rev Saúde Pública. 1973;7:21-28.

11. Medeiros C, Scholte RGC, D’Ávila S, Caldeira RL, Carvalho OS. Spatial distribution of Lymnaeidae (Mollusca, Basommatophora), intermediate host of Fasciola hepatica Linnaeus, 1758 (Trematoda, Digenea) in Brazil. Rev Inst Med Trop São Paulo. 2014;56(3):23552.

12. Mansur MCD, Santos CP, Pereira D, Bergonci PEA, Callil CT. Moluscos límnicos - Bivalves. In: Latini AO, Resende DC, Pombo VB, Coradin L, editors. Espécies exóticas invasoras de águas continentais no Brasil. Brasília: Ministério do Meio Ambiente; 2016: p. 127-75.

13. Fernandez MA, Mattos AC, Silva EF, Santos SB, Thiengo SC. A malacological survey in the Manso Power plant, State of Mato Grosso, Brazil: new records of freshwater snails, including transmitters of schistosomiasis and exotic species. Rev Soc Bras Med Trop. 2014;47(4):498-506.

14. Fernandez MA, Thiengo SC. Are major water impoundments contributing to freshwater mollusc knowledge and conservation in Brazil? Tentacle. 2016;24:29-31.

15. Lacerda LEM, Miyahira IC, Santos SB. First record and range extension of the freshwater limpet Gundlachia radiata (Guilding, 1828) (Mollusca: Gastropoda: Planorbidae) from southeast Brazil. Check List 2013;9(1):125-8. 